\title{
Bluebellite and mojaveite, two new minerals from the central Mojave Desert, California, USA
}

\author{
S. J. Mills ${ }^{1} *$, A. R. KampF ${ }^{2}$, A. G. Christy ${ }^{3}$, R. M. Housley ${ }^{4}$, G. R. Rossman ${ }^{4}$, R. E. Reynolds ${ }^{5}$ And $^{2}$ \\ J. MARTY ${ }^{6}$ \\ 1 Geosciences, Museum Victoria, GPO Box 666, Melbourne 3001, Victoria, Australia \\ 2 Mineral Sciences Department, Natural History Museum of Los Angeles County, 900 Exposition Boulevard, Los \\ Angeles, CA 90007, USA \\ 3 Centre for Advanced Microscopy, Australian National University, Canberra, ACT 0200, Australia \\ 4 Division of Geological and Planetary Sciences, California Institute of Technology, Pasadena, CA 91125, USA \\ 5220 South Buena Vista Street, Redlands, CA 92373, USA \\ 65199 E. Silver Oak Road, Salt Lake City, UT 84108, USA
}

[Received 6 March 2014; Accepted 5 May 2014; Associate Editor: G. D. Gatta]

\section{ABSTRACT}

Bluebellite, $\mathrm{Cu}_{6}\left[\mathrm{I}^{5+} \mathrm{O}_{3}(\mathrm{OH})_{3}\right](\mathrm{OH})_{7} \mathrm{Cl}$ and mojaveite, $\mathrm{Cu}_{6}\left[\mathrm{Te}^{6+} \mathrm{O}_{4}(\mathrm{OH})_{2}\right](\mathrm{OH})_{7} \mathrm{Cl}$, are new secondary copper minerals from the Mojave Desert. The type locality for bluebellite is the D shaft, Blue Bell claims, near Baker, San Bernardino County, California, while cotype localities for mojaveite are the E pit at Blue Bell claims and also the Bird Nest drift, Otto Mountain, also near Baker. The two minerals are very similar in their properties. Bluebellite is associated particularly with murdochite, but also with calcite, fluorite, hemimorphite and rarely dioptase in a highly siliceous hornfels. It forms bright bluishgreen plates or flakes up to $\sim 20 \mu \mathrm{m} \times 20 \mu \mathrm{m} \times 5 \mu \mathrm{m}$ in size that are usually curved. The streak is pale bluish green and the lustre is adamantine, but often appears dull because of surface roughness. It is non-fluorescent. Bluebellite is very soft (Mohs hardness $\sim 1$ ), sectile, has perfect cleavage on $\{001\}$ and an irregular fracture. The calculated density based on the empirical formula is $4.746 \mathrm{~g} \mathrm{~cm}^{-3}$. Bluebellite is uniaxial (-), with mean refractive index estimated as 1.96 from the Gladstone-Dale relationship. It is pleochroic $O$ (bluish green) $\gg>E$ (nearly colourless). Electron microprobe analyses gave the empirical formula $\mathrm{Cu}_{5.82} \mathrm{I}_{0.99} \mathrm{Al}_{0.02} \mathrm{Si}_{0.12} \mathrm{O}_{3.11}(\mathrm{OH})_{9.80} \mathrm{Cl}_{1.09}$ based on $14(\mathrm{O}+\mathrm{Cl})$ a.p.f.u. The Raman spectrum shows strong iodate-related bands at 680,611 and $254 \mathrm{~cm}^{-1}$. Bluebellite is trigonal, space group $R 3$, with the unit-cell parameters: $a=8.3017(5), c=13.259(1) \AA, V=791.4(1) \AA^{3}$ and $Z=$ 3 . The eight strongest lines in the powder X-ray diffraction (XRD) pattern are $\left[d_{\text {obs }} / \AA(I)(h k l)\right]$ : $4.427(99)(003), 2.664(35)(211), 2.516(100)(21 \overline{2}), 2.213(9)(006), 2.103(29)(033,214)$, $1.899(47)(312,21 \overline{5}), 1.566(48)(140,217)$ and $1.479(29)(045,14 \overline{3}, 324)$.

Mojaveite occurs at the Blue Bell claims in direct association with cerussite, chlorargyrite, chrysocolla, hemimorphite, kettnerite, perite, quartz and wulfenite, while at the Bird Nest drift, it is associated with andradite, chrysocolla, cerussite, burckhardtite, galena, goethite, khinite, mcalpineite, thorneite, timroseite, paratimroseite, quartz and wulfenite. It has also been found at the Aga mine, Otto Mountain, with cerussite, chrysocolla, khinite, perite and quartz. Mojaveite occurs as irregular aggregates of greenish-blue plates flattened on $\{001\}$ and often curved, which rarely show a hexagonal outline, and also occurs as compact balls, from sky blue to medium greenish blue in colour. Aggregates and balls are up to $0.5 \mathrm{~mm}$ in size. The streak of mojaveite is pale greenish blue, while the lustre may be adamantine, pearly or dull, and it is non-fluorescent. The Mohs hardness is $\sim 1$. It is sectile, with perfect cleavage on $\{001\}$ and an irregular fracture. The calculated density is $4.886 \mathrm{~g} \mathrm{~cm}^{-3}$, based on

* E-mail: smills@museum.vic.gov.au

DOI: 10.1180/minmag.2014.078.5.15 
the empirical formulae and unit-cell dimensions. Mojaveite is uniaxial (-), with mean refractive index estimated as 1.95 from the Gladstone-Dale relationship. It is pleochroic $O$ (greenish blue) $>>E$ (light greenish blue). The empirical formula for mojaveite, based on $14(\mathrm{O}+\mathrm{Cl})$ a.p.f.u., is $\mathrm{Cu}_{5.92} \mathrm{Te}_{1.00} \mathrm{~Pb}_{0.08} \mathrm{Bi}_{0.01} \mathrm{O}_{4}(\mathrm{OH})_{8.94} \mathrm{Cl}_{1.06}$. The most intense Raman bands occur at 694,654 (poorly resolved), 624, 611 and $254 \mathrm{~cm}^{-1}$. Mojaveite is trigonal, space group $R 3$, with the unit-cell parameters: $a=8.316(2), c=13.202(6) \AA$ and $V=790.7(1) \AA^{3}$. The eight strongest lines in the powder XRD pattern are $\left[d_{\text {obs }} / \AA(I)(h k l)\right]: 4.403(91)(003), 2.672(28)(211), 2.512(100)(21 \overline{2}), 2.110(27)(033,214)$, $1.889(34)(312,21 \overline{5}, 22 \overline{3}), 1.570(39)(404,140,217), 1.481(34)(045,14 \overline{3}, 324)$ and $1.338(14)(422)$. Diffraction data could not be refined, but stoichiometries and unit-cell parameters imply that bluebellite and mojaveite are very similar in crystal structure. Structure models that satisfy bondvalence requirements are presented that are based on stackings of brucite-like $\mathrm{Cu}_{6} M X_{14}$ layers, where $M=(\mathrm{I}$ or $\mathrm{Te})$ and $X=(\mathrm{O}, \mathrm{OH}$ and $\mathrm{Cl})$. Bluebellite and mojaveite provide a rare instance of isotypy between an iodate containing $\mathrm{I}^{5+}$ with a stereoactive lone electron pair and a tellurate containing $\mathrm{Te}^{6+}$ with no lone pair.

Keywords: Bluebellite, mojaveite, new mineral, iodate, tellurate, crystal structure, Raman spectroscopy, Otto Mountain, Blue Bell Claim, California.

\section{Introduction}

THE Mojave Desert of California, in the southwestern United States of America, contains thousands of old mines and prospects, the vast majority of which were never economically profitable. However, a few deposits, though they produced little ore, have yielded a noteworthy variety of rare and unusual minerals. One of these deposits is the Blue Bell claims in the Soda Mountains, $\sim 11 \mathrm{~km}$ west of Baker, San Bernardino County, California $\left(35^{\circ} 14^{\prime} 31^{\prime \prime} \mathrm{N}, 116^{\circ} 12^{\prime} 17^{\prime \prime} \mathrm{W}\right)$, which has been a prolific producer of microcrystals of rare species for six decades (Crowley, 1977; Maynard et al., 1984; Kampf et al., 2009; Mills et al., 2010). Importantly, the Blue Bell claims are the type locality for the new minerals fluorphosphohedyphane (Kampf and Housley, 2011), plumbophyllite (Kampf et al., 2009) and reynoldsite (Kampf et al., 2012b). A little farther east, another world-class mineral locality is found at Otto Mountain, $1.5 \mathrm{~km}$ northwest of Baker (Kampf et al., 2010a; Housley et al., 2011). Twelve new secondary minerals (Table 1) have been described previously from this remarkable mineral assemblage. Here we announce two new minerals, bluebellite and mojaveite, which were approved recently by the International Mineralogical Association Commission on New Minerals, Nomenclature and Classification (IMA2012-120, Mills et al., 2014a and IMA2012-121, Mills et al., 2014b, respectively). Bluebellite is named for its type locality, the Blue Bell claims. Mojaveite is named for the Mojave Desert, in which both of its type localities are located.
Eight cotype specimens of bluebellite are housed in the collections of the Mineral Sciences Department, Natural History Museum of Los Angeles County, catalogue numbers 64083 to 64090 , and one in the Geosciences collections, Museum Victoria, Melbourne, Victoria, Australia, catalogue number M52832. For mojaveite, four cotype specimens are housed in the collections of the Mineral Sciences Department, Natural History Museum of Los Angeles County, catalogue numbers 64091 and 64092 (from the Blue Bell claims) and 64093 and 64094 (from the Bird Nest drift on Otto Mountain). Part of 64094 has been registered the Geosciences collections, Museum Victoria, under catalogue number M53019.

\section{Occurrence}

Bluebellite was discovered by the late John Jenkins of Redlands, California in 1983 at the shallow D shaft, Blue Bell claims, where worldclass specimens of quetzalcoatlite were also found. Bluebellite occurs in direct association with murdochite (the latter often as pseudomorphs after wulfenite; Fig. 1), calcite, fluorite and hemimorphite in a highly siliceous hornfels. Rarely, dioptase is also found in association with bluebellite.

Mojaveite was discovered by one of the authors (JM) in 2005 on Otto Mountain at the Aga mine $\left(35.27215^{\circ} \mathrm{N}, 116.09487^{\circ} \mathrm{W}\right.$, elevation 1055 feet) and at the Bird Nest drift $\left(35.27677^{\circ} \mathrm{N}\right.$, $116.09927^{\circ} \mathrm{W}$ ) and in 2008 in the small $\mathrm{E}$ pit at the Blue Bell claims. At the Blue Bell claims, mojaveite occurs in direct association with 
TABLE 1. New minerals previously described from Otto Mountain.

\begin{tabular}{lll}
\hline Mineral & \multicolumn{1}{c}{ Ideal Formula } & \multicolumn{1}{c}{ Reference } \\
\hline Ottoite & $\mathrm{Pb}_{2} \mathrm{Te}^{6+} \mathrm{O}_{5}$ & Kampf et al. $(2010 a)$ \\
Housleyite & $\mathrm{Pb}_{6} \mathrm{Cu}^{2+} \mathrm{Te}_{4}^{6+} \mathrm{O}_{18}(\mathrm{OH})_{2}$ & Kampf et al. $(2010 b)$ \\
Thorneite & $\mathrm{Pb}_{6}\left(\mathrm{Te}_{2}^{6+} \mathrm{O}_{10}\right)\left(\mathrm{CO}_{3}\right) \mathrm{Cl}_{2}\left(\mathrm{H}_{2} \mathrm{O}\right)$ & Kampf et al. $(2010 c)$ \\
Markcooperite & $\mathrm{Pb}_{2}\left(\mathrm{UO}_{2}\right) \mathrm{Te}^{4+} \mathrm{O}_{6}$ & Kampf et al. $(2010 d)$ \\
Timroseite & $\mathrm{Pb}_{2} \mathrm{Cu}_{5}^{2+}\left(\mathrm{Te}^{6+} \mathrm{O}_{6}\right)_{2}(\mathrm{OH})_{2}$ & Kampf et al. $(2010 e)$ \\
Paratimroseite & $\mathrm{Pb}_{2} \mathrm{Cu}_{4}^{2+}\left(\mathrm{Te}^{6+} \mathrm{O}_{6}\right)_{2}\left(\mathrm{H}_{2} \mathrm{O}\right)_{2}$ & Kampf et al. $(2010 e)$ \\
Telluroperite & $\mathrm{Pb}_{3} \mathrm{Te}^{4+} \mathrm{O}_{4} \mathrm{Cl}_{2}$ & Kampf et al. $(2010 f)$ \\
Chromschieffelinite & $\mathrm{Pb}_{10} \mathrm{Te}_{6}^{6+} \mathrm{O}_{20}\left(\mathrm{CrO}_{4}\right)\left(\mathrm{H}_{2} \mathrm{O}\right)_{5}$ & Kampf et al. $(2012 a)$ \\
Fuettererite & $\mathrm{Pb}_{3} \mathrm{Cu}_{6}^{2+} \mathrm{Te}^{6+} \mathrm{O}_{6}(\mathrm{OH})_{7} \mathrm{Cl}_{5}$ & Kampf et al. $(2013 a)$ \\
Agaite & $\mathrm{Pb}_{3} \mathrm{Cu}^{2+} \mathrm{Te}^{6+} \mathrm{O}_{5}(\mathrm{OH})_{2}\left(\mathrm{CO}_{3}\right)$ & Kampf et al. $(2013 b)$ \\
Bairdite & $\mathrm{Pb}_{2} \mathrm{Cu}_{4}^{2+} \mathrm{Te}_{2}^{6+} \mathrm{O}_{10}(\mathrm{OH})_{2}\left(\mathrm{SO}_{4}\right)\left(\mathrm{H}_{2} \mathrm{O}\right)$ & Kampf et al. $(2013 c)$ \\
Eckhardite & $\left(\mathrm{Ca}_{3} \mathrm{~Pb}^{2} \mathrm{Cu}^{2+} \mathrm{Te}^{6+} \mathrm{O}_{5}\left(\mathrm{H}_{2} \mathrm{O}\right)\right.$ & Kampf et al. $(2013 d)$ \\
& &
\end{tabular}

cerussite, chlorargyrite, chrysocolla, hemimorphite, kettnerite, perite, quartz and wulfenite. At the Aga mine, mojaveite is associated with cerussite, chrysocolla, khinite, perite and quartz. At the Bird Nest drift, it is associated with andradite, chrysocolla, cerussite, burckhardtite, galena, goethite, khinite, mcalpineite, thorneite, timroseite, paratimroseite, quartz and wulfenite.

Bluebellite and mojaveite are interpreted as having formed from the decomposition of the primary minerals hessite and chalcopyrite under mildly acidic conditions. The source of the iodine at the Blue Bell claims and at Otto Mountain is unknown, but it may be derived from recycling of marine sediments of Palaeozoic or Mesozoic age (c.f. Walker et al., 2002). It is interesting to note that the only other locality in California where

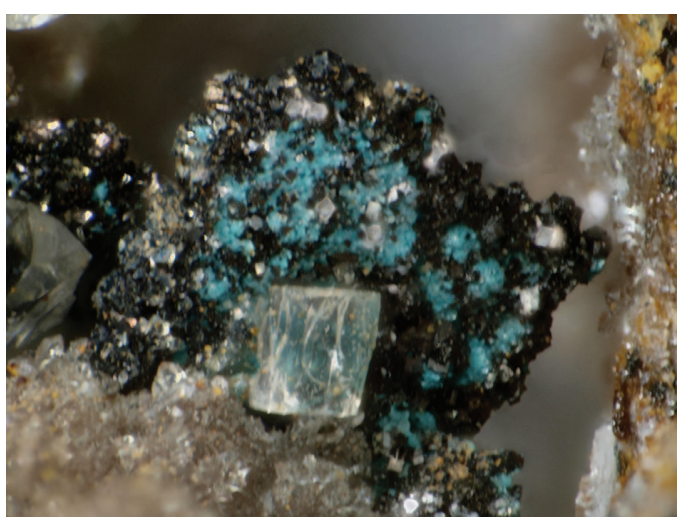

FIG. 1. Bluebellite with fluorite on murdochite (pseudomorphs after wulfenite) from the Blue Bell claims (Field of view: $2 \mathrm{~mm}$ ). secondary iodine minerals have been identified is the Clear Creek claims, San Benito County (Dunning et al., 2005).

\section{Physical and optical properties}

Bluebellite occurs as bright bluish-green plates or flakes up to $\sim 20 \mu \mathrm{m} \times 20 \mu \mathrm{m} \times 5 \mu \mathrm{m}$ in size. Plates are generally curved and flattened on $\{001\}$ and are intergrown in irregular aggregates (Fig. 2). The only forms observed are $\{001\}$ and $\{00 \overline{1}\}$; no bounding forms could be determined.

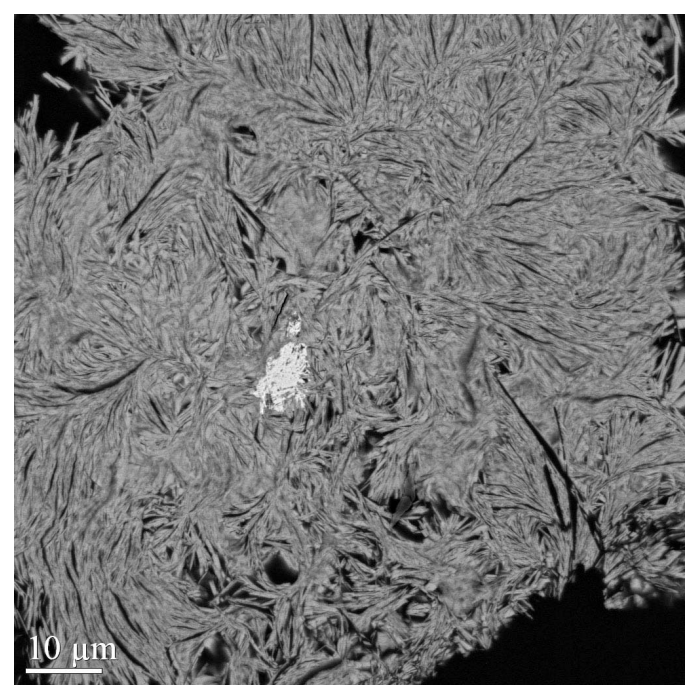

FIG. 2. SEM image showing curved plates of bluebellite in the polished probe mount highlighting the difficulty in working with the material. 


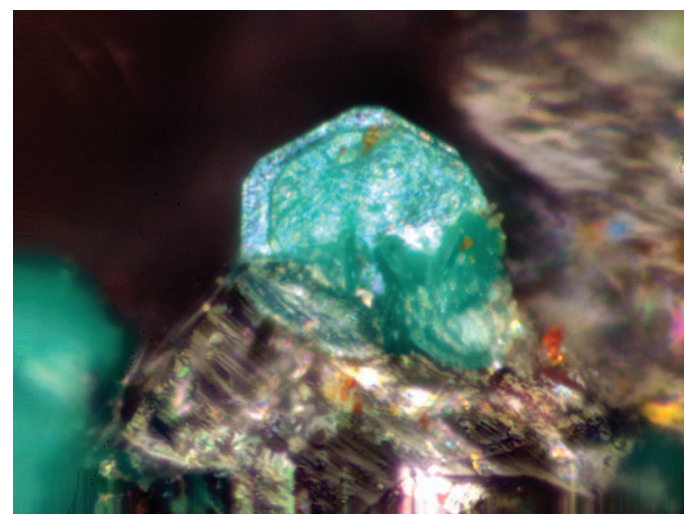

FIG. 3. Crystals of mojaveite on quartz from Otto Mountain (Field of view: $1 \mathrm{~mm}$ ).

Bluebellite has a pale bluish-green streak, an adamantine lustre, which often appears dull because of the rough surfaces of plates, and is non-fluorescent. The hardness is very low probably $\sim 1$ on the Mohs scale, based upon its behaviour when manipulated under magnification. Bluebellite is sectile, has perfect cleavage on $\{001\}$ and has an irregular fracture.

Mojaveite occurs as greenish-blue plates flattened on $\{001\}$, which rarely show a hexagonal outline (Fig. 3). Although no crystal forms could be measured, the observed morphology is consistent with the forms $\{001\}$, $\{00 \overline{1}\},\{100\},\{010\},\{110\}$ and $\{\overline{1} 20\}$ (Fig. 4). The plates are generally curved, and are intergrown in irregular aggregates (Fig. 5). Mojaveite also occurs as compact balls, varying

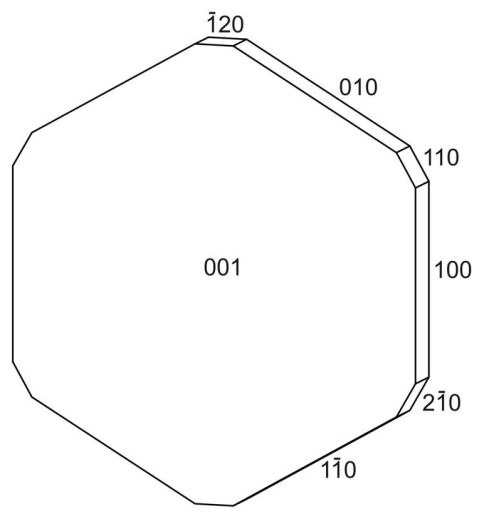

FIG. 4. Crystal drawing of mojaveite (clinographic projection in non-standard orientation).

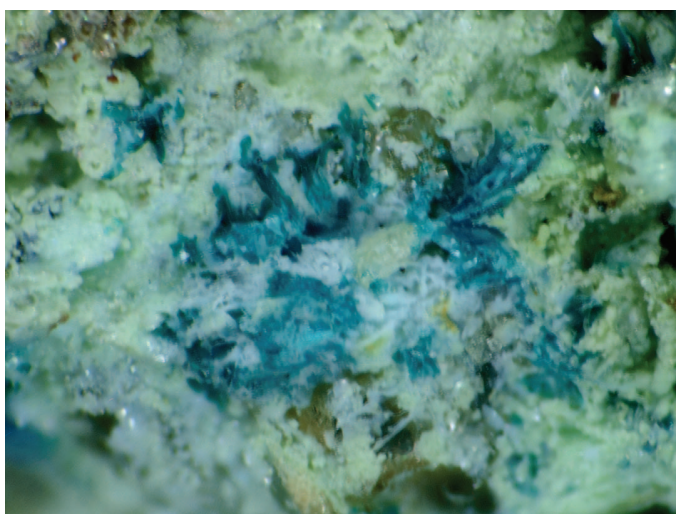

FIG. 5. Irregular curved greenish-blue plates of mojaveite intermixed with kettnerite and chlorargyrite from the Blue Bell claims (Field of view: $3 \mathrm{~mm}$ ).

in colour from sky blue to medium greenish blue (Fig. 6). Both individual plates and compact balls reach $0.5 \mathrm{~mm}$ in maximum dimension. The streak of mojaveite is pale greenish blue, the lustre may be adamantine, pearly or dull, and the mineral is non-fluorescent. The hardness is probably $\sim 1$ on the Mohs scale, based upon its behaviour when manipulated under magnification. The mineral is sectile, has perfect cleavage on $\{001\}$ and has an irregular fracture.

The densities could not be measured for either mineral, because they are greater than those of available high-density liquids and there was insufficient material for physical measurement. The calculated density is $4.746 \mathrm{~g} \mathrm{~cm}^{-3}$ for

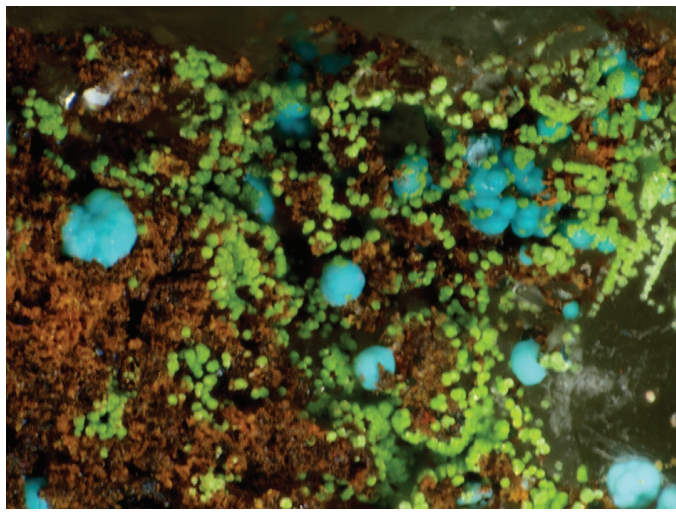

FIG. 6. Greenish-blue balls of mojaveite with olive green mcalpineite on goethite from the Bird Nest drift (Field of view: $3 \mathrm{~mm}$ ). 
bluebellite and $4.886 \mathrm{~g} \mathrm{~cm}^{-3}$ for mojaveite, based on the empirical formulae and unit-cell dimensions.

Optically, both minerals are uniaxial $(-)$, with $\omega$ and $\varepsilon \gg 1.8$. Refractive indices could not be measured directly, due to rapid reaction with high-index immersion fluids. Using the Gladstone-Dale relationship, they are estimated as $n_{\text {ave }}=1.96$ for bluebellite and 1.95 for mojaveite. The pleochroism of bluebellite is: $O$ (bluish green) $\gg E$ (nearly colourless), and for mojaveite is: $O$ (greenish blue) $\gg E$ (light greenish blue).

\section{Chemical composition}

Quantitative chemical analyses of bluebellite and mojaveite (5 replicates each) were carried out using a JEOL8200 electron microprobe (wavelength-dispersive spectroscopy mode, $20 \mathrm{kV}$, $5 \mathrm{nA}, 20 \mu \mathrm{m}$ beam diameter for bluebellite; $15 \mathrm{kV}, 5 \mathrm{nA}, 5 \mu \mathrm{m}$ beam diameter for mojaveite) at the Division of Geological and Planetary Sciences, California Institute of Technology. Analytical results are given in Table 2. No other elements were detected in energy-dispersive spectroscopy analyses. There was insufficient material for $\mathrm{CHN}$ analyses, so $\mathrm{H}_{2} \mathrm{O}$ was calculated on the basis of $14(\mathrm{O}+\mathrm{Cl})$ atoms per formula unit (a.p.f.u.), derived from the crystalstructure models for these minerals, which are discussed below. It should be noted that bluebellite occurs in porous aggregates of bent plates (Fig. 2), which take a very poor polish. In addition, the mineral is prone to electron beam damage, which required the use of a large beam diameter and a lower beam current. The porous nature of the sample led to the incorporation of a lot of void space in the analysis regions and hence low totals. Although mojaveite is also prone to electron beam damage, it is more stable than bluebellite, so a smaller beam diameter could be used.

The empirical formula for bluebellite, based on $14(\mathrm{O}+\mathrm{Cl})$ a.p.f.u. is, with rounding errors, $\mathrm{Cu}_{5.82} \mathrm{I}_{0.99} \mathrm{Al}_{0.02} \mathrm{Si}_{0.12} \mathrm{O}_{3.11}(\mathrm{OH})_{9.80} \mathrm{Cl}_{1.09}$. The simplified formula is $\mathrm{Cu}_{6}\left[\mathrm{IO}_{3}(\mathrm{OH})_{3}\right](\mathrm{OH})_{7} \mathrm{Cl}$, which requires $\mathrm{CuO}$ 62.66, $\mathrm{I}_{2} \mathrm{O}_{5} 21.99, \mathrm{Cl} 4.65$, $\mathrm{H}_{2} \mathrm{O} 11.83, \mathrm{O}=\mathrm{Cl}-1.05$, total 100 wt. $\%$. The empirical formula for mojaveite from Otto Mountain is $\mathrm{Cu}_{5.92} \mathrm{Te}_{1.00} \mathrm{~Pb}_{0.08} \mathrm{Bi}_{0.01} \mathrm{O}_{4}$ $(\mathrm{OH})_{8.94} \mathrm{Cl}_{1.06}$. The simplified formula is $\mathrm{Cu}_{6}\left[\mathrm{TeO}_{4}(\mathrm{OH})_{2}\right](\mathrm{OH})_{7} \mathrm{Cl}$, which requires $\mathrm{CuO}$ 62.68, $\mathrm{TeO}_{3}$ 23.06, $\mathrm{Cl} 4.66, \mathrm{H}_{2} \mathrm{O} 10.65, \mathrm{O}=\mathrm{Cl}$ -1.05 , total 100 wt.\%. From the formulae, one can see that mojaveite appears to be the tellurate

TABLE 2. Analytical data for (a) bluebellite, (b) mojaveite.

\begin{tabular}{lccll}
\hline Constituent & Average wt. $\%$ & Range & SD & Standard \\
\hline (a) Bluebellite & & & & \\
$\mathrm{CuO}$ & 48.62 & $47.81-50.47$ & 0.91 & Cu metal \\
$\mathrm{Al}_{2} \mathrm{O}_{3}$ & 0.12 & $0-0.23$ & 0.40 & Anorthite \\
$\mathrm{SiO}_{2}$ & 0.75 & $0.71-0.83$ & 0.03 & Anorthite \\
$\mathrm{I}_{2} \mathrm{O}_{5}$ & 17.26 & $16.90-17.78$ & 0.24 & RbI \\
$\mathrm{Cl}$ & 4.06 & $3.99-4.14$ & 0.06 & Sodalite \\
$\mathrm{H}_{2} \mathrm{O}_{\text {calc }}$ & 9.27 & & & \\
$\mathrm{O}=\mathrm{Cl}$ & -0.92 & & & \\
$\mathrm{Total}$ & 79.16 & & & \\
& & & & \\
$(\mathrm{~b}) \mathrm{Mojaveite}$ & 56.74 & $56.21-57.49$ & 0.54 & Cuprite \\
$\mathrm{CuO}$ & 2.14 & $1.46-2.45$ & 0.48 & Bi metal \\
$\mathrm{PbO}$ & 0.33 & $0-0.50$ & 0.20 & Te metal \\
$\mathrm{Bi} \mathrm{O}_{3}$ & 21.12 & $20.86-21.57$ & 0.32 & Sodalite \\
$\mathrm{TeO}$ & $4.38-4.60$ & 0.09 & \\
$\mathrm{Cl}$ & 9.51 & & & \\
$\mathrm{H}_{2} \mathrm{O}_{\text {calc }}$ & 9.71 & & & \\
$\mathrm{O}=\mathrm{Cl}$ & & & & \\
$\mathrm{Total}$ & 93.53 & & & \\
& & & & \\
\hline
\end{tabular}


analogue of bluebellite, with $\mathrm{Te}^{6+} \mathrm{O}$ replacing $\mathrm{I}^{5+}(\mathrm{OH})$. It is somewhat unusual to see a cation with stereoactive lone pair electrons playing the same structural role as one without a lone pair when the valences are this large $(+5$ for I with lone pair and +6 for Te without), the bond valences are concomitantly large, and the lone pair is strongly stereoactive. However, such behaviour is well known for larger, low-valence cations with high coordination numbers, such as the $\mathrm{Pb}^{2+}-\mathrm{Ba}^{2+}$ pair.

\section{Raman spectroscopy}

Raman spectra were obtained with a Renishaw M-1000 microRaman spectrometer system operating with a $514.3 \mathrm{~nm}$ Cobolt solid-state laser through a $50 \times$ objective that produced $2 \mathrm{~mW}$ on an $\sim 2 \mu \mathrm{m}$ diameter spot on a single flat crystal of bluebellite, probably on the (001) face, removed from a crystal aggregate. A $4 \mu \mathrm{m}$ diameter spot was used on a crystal of mojaveite, also probably on the (001) face. Care was taken to be certain that after the spectra were obtained, no visible beam damage was apparent on the sample at the analysis spot.

Frost (2009) and Frost and Keeffe (2009a,b) discussed the Raman spectra of tellurate minerals in relation to previously characterized, simple tellurate compounds. Intense tellurate symmetric stretching modes are observed in the $615-810 \mathrm{~cm}^{-1}$ range for such compounds and the few tellurate minerals studied previously. Corresponding tellurate bending modes generally occur in the $290-460 \mathrm{~cm}^{-1}$ region. Kampf et al. $(2013 c, d)$ present the Raman spectra of the tellurate minerals bairdite and eckhardite, which also show features in these wavenumber ranges.

In the spectrum of mojaveite, the most intense band, probably corresponding to a tellurate symmetrical stretching mode, occurs at $694 \mathrm{~cm}^{-1}$. It is accompanied by a less intense band at $624 \mathrm{~cm}^{-1}$ and a poorly resolved band between them at $\sim 654 \mathrm{~cm}^{-1}$. Other more intense bands occur at 555,510 and $254 \mathrm{~cm}^{-1}$. Other significant features are observed at $475,414,286$, 233, 203 and $172 \mathrm{~cm}^{-1}$. A set of less intense features occur in the 1112 to $967 \mathrm{~cm}^{-1}$ region. Features in the $\mathrm{OH}$ region near $3500 \mathrm{~cm}^{-1}$ are very weak.

Intense iodate symmetric stretching modes have been observed previously in the $720-803 \mathrm{~cm}^{-1}$ range for simple iodate compounds. The corresponding iodate bending modes in simple systems occur in the $300-430 \mathrm{~cm}^{-1}$ range, and the more complex lattice modes occur generally below $300 \mathrm{~cm}^{-1}$ (Maroni and Hathaway, 1972; Schellenschläger et al., 2001; Girase et al., 2013). Bluebellite, of course, is not a simple iodate compound. In the bluebellite spectrum, the most intense band, probably corresponding to the iodate symmetric stretching, occurs at a somewhat lower frequency $\left(680 \mathrm{~cm}^{-1}\right)$. Other more intense bands occur at 611 and $254 \mathrm{~cm}^{-1}$. Other less intense features are observed at 1007, 544, 502, 254, 203 and $172 \mathrm{~cm}^{-1}$.

As is the case for the mojaveite spectrum, features in the $\mathrm{OH}$ region near $3500 \mathrm{~cm}^{-1}$ are very weak. It is worth noting that the $\mathrm{OH}$ groups are oriented with their dominant component in the direction of the $z$ axis. Thus, it would be expected that the (001) orientation is not aligned in a direction to efficiently activate $\mathrm{OH}$ modes.

It is important to note that there is a striking similarity between the Raman spectra of bluebellite and mojaveite (Fig. 7). The crystallographic studies, discussed below, indicate that both minerals have similar structures, but with iodate in bluebellite replaced by tellurate in mojaveite. The $\mathrm{I}^{5+}$ and $\mathrm{Te}^{6+}$ cations are almost identical in mass (126.9 and $127.6 \mathrm{~g} / \mathrm{mol}$, respectively). Both are in $3+3$ distorted octahedral coordination by oxygen, but the mean bond valence is substantially lower for $\mathrm{I}^{5+}(5 / 6$ as opposed to 1 valence unit (vu)). Likewise, the bond valence of the stronger bonds is lower, albeit to a lesser degree given the greater distortion of the iodine coordination polyhedron (1.21 as opposed to $1.29 \mathrm{vu}$, see Tables 6 and 9 below). We would expect the bond-force constants for the iodate to be correspondingly weaker. In line with this expectation, it is noteworthy that the energies of all the bluebellite bands above $450 \mathrm{~cm}^{-1}$ are shifted to lower energies than the corresponding mojaveite features.

\section{Crystallography}

Single-crystal X-ray studies could not be carried out due to the poor quality of the crystals for both bluebellite and mojaveite. On a bluebellite crystal which showed some spots, the observed reflections were compatible with a rhombohedral lattice having $a=b=8.3 \AA$, but severe streaking parallel to $c^{*}$ hampered any structure solution.

Powder XRD data were obtained using a Rigaku R-AXIS Rapid II curved imaging plate microdiffractometer, with monochromatized $\mathrm{Mo} K_{\alpha}$ radiation. Observed $d$ spacings and 


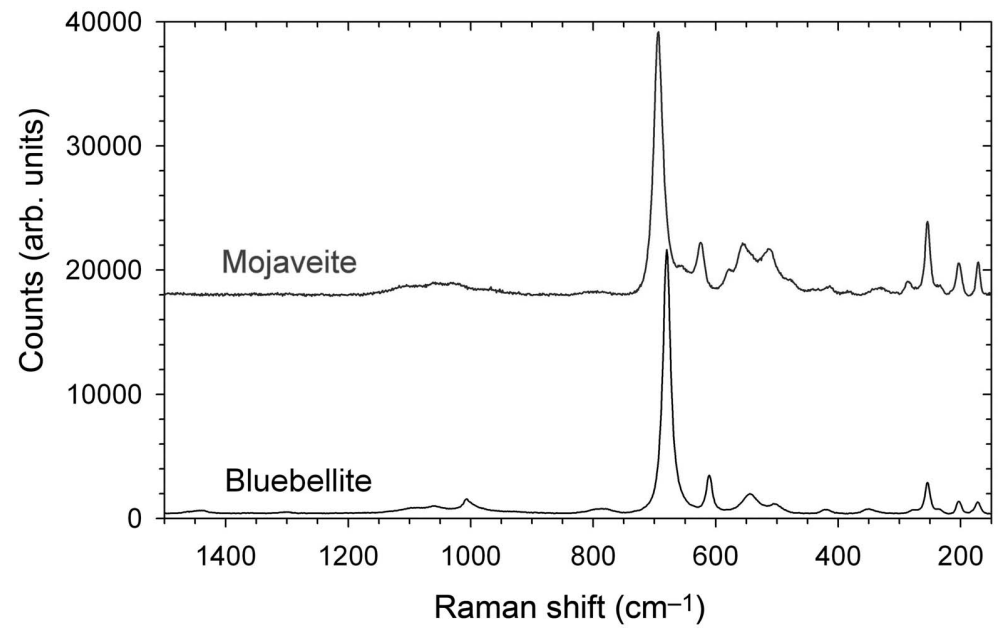

FIG. 7. Raman spectra of bluebellite and mojaveite.

intensities were derived by profile fitting using JADE 2010 software (Materials Data, Inc.). Data for both minerals are given in Table 3. The powder patterns of bluebellite and mojaveite are virtually indistinguishable in appearance (Fig. 8). Unit-cell parameters (in $R 3$ ) refined from the powder data using JADE 2010 with whole-pattern fitting are: $a=8.3017(5), c=13.259(1) \AA$ and $V=$ 791.4(1) $\AA^{3}$ for bluebellite and $a=8.316(2), c=$ 13.202(6) $\AA$ and $V=790.7(1) \AA^{3}$ for mojaveite.
The $R U B Y$ program for $a b$ initio structure solution from powder data (Materials Data Inc.) was used initially for the location of the heavy atoms $\mathrm{Cu}, \mathrm{I}$ and $\mathrm{Cl}$ in bluebellite. $R U B Y$ showed three $\mathrm{CuO}_{4}$ squares linked by corners to form a ring surrounding a threefold rotation axis. However, the overall $\mathrm{Cu}$ :I stoichiometry was incorrect. It became possible to propose a structural model for bluebellite that was consistent with both the analytical data and the unit-cell

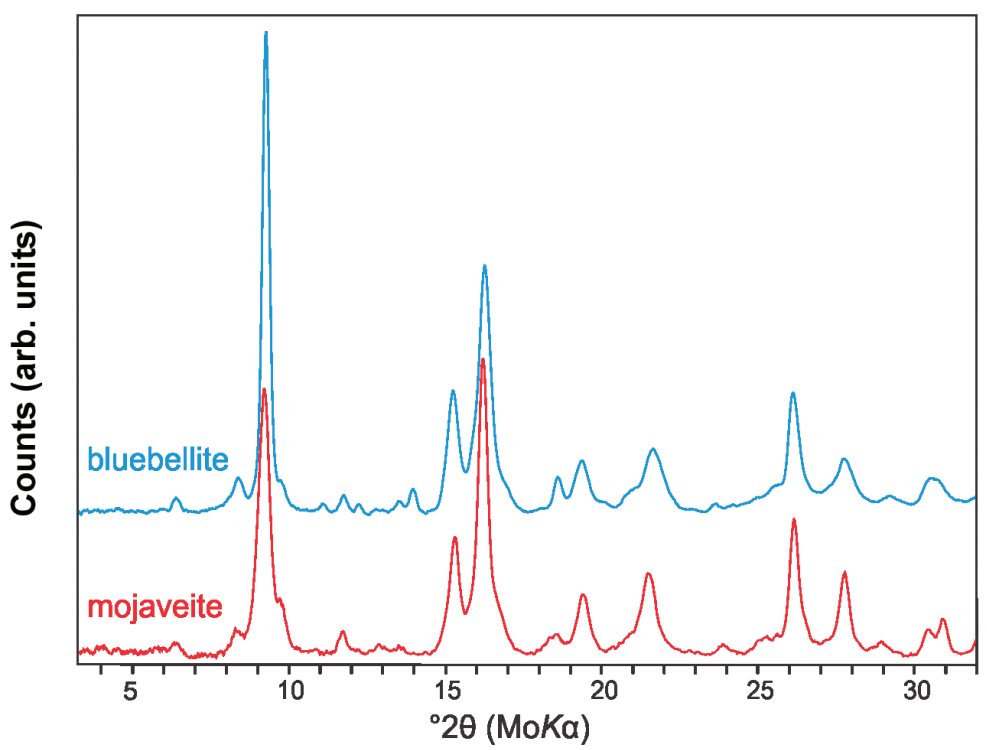

FIG. 8. Powder XRD of bluebellite and mojaveite. 
TABLE 3. Powder XRD data. Eight strongest distinct powder lines indicated in bold.

\begin{tabular}{|c|c|c|c|c|}
\hline$I_{\mathrm{obs}}$ & $d_{\mathrm{obs}}$ & $d_{\text {calc }}$ & $I_{\text {calc }}$ & $h k l$ \\
\hline \multicolumn{5}{|c|}{ (a) Bluebellite. } \\
\hline 6 & 6.37 & 6.3202 & 10 & 101 \\
\hline 8 & 4.880 & 4.8737 & 10 & $\begin{array}{lll}0 & 1 & 2\end{array}$ \\
\hline 99 & 4.427 & 4.4197 & 92 & $\begin{array}{lll}0 & 0 & 3\end{array}$ \\
\hline 2 & 4.165 & 4.1509 & 7 & 110 \\
\hline 4 & 3.475 & 3.4695 & 1 & $\begin{array}{lll}0 & 2 & 1\end{array}$ \\
\hline \multirow{2}{*}{2} & 3.162 & 3.1601 & 4 & 202 \\
\hline & & 3.0257 & 5 & 113 \\
\hline 5 & 3.024 & 3.0102 & 13 & 104 \\
\hline 35 & 2.664 & 2.6620 & 27 & $\begin{array}{lll}2 & 1 & 1\end{array}$ \\
\hline \multirow[t]{2}{*}{100} & 2.516 & 2.5143 & 100 & $21 \overline{2}$ \\
\hline & & 2.4880 & 3 & 015 \\
\hline \multirow[t]{2}{*}{7} & 2.436 & 2.4369 & 11 & 024 \\
\hline & & 2.3965 & 7 & $\begin{array}{lll}30 & 0\end{array}$ \\
\hline \multirow[t]{3}{*}{9} & 2.213 & 2.2098 & 1 & $\begin{array}{lll}0 & 0 & 6\end{array}$ \\
\hline & & 2.1340 & 4 & 205 \\
\hline & & 2.1067 & 9 & $\begin{array}{lll}033 \\
\end{array}$ \\
\hline \multirow[t]{3}{*}{29} & 2.103 & 2.1015 & 21 & 214 \\
\hline & & 2.0754 & 6 & 220 \\
\hline & 19605 & 1.9718 & 4 & $\begin{array}{lll}3 & 1 & \overline{1}\end{array}$ \\
\hline 6 & 1.9605 & 1.9506 & 13 & 116 \\
\hline
\end{tabular}

$I_{\text {obs }} \quad d_{\text {obs }} \quad d_{\text {calc }} \quad I_{\text {calc }} \quad h k l$

(a) Bluebellite.

\begin{tabular}{|c|c|c|c|c|}
\hline \multirow{4}{*}{47} & \multirow{3}{*}{1.8990} & 1.9095 & 12 & 312 \\
\hline & & 1.8979 & 40 & $21 \overline{5}$ \\
\hline & & 1.8786 & 5 & $22 \overline{3}$ \\
\hline & & 1.8316 & 4 & 107 \\
\hline \multirow[t]{2}{*}{3} & \multirow[t]{2}{*}{1.7832} & 1.7811 & 1 & $\begin{array}{lll}4 & 0 & 1\end{array}$ \\
\hline & & 1.7347 & 1 & 042 \\
\hline \multirow[t]{3}{*}{4} & \multirow[t]{3}{*}{1.7091} & 1.7087 & 4 & 31 \\
\hline & & 1.6757 & 8 & $\begin{array}{lll}027 & 7\end{array}$ \\
\hline & & 1.6368 & 2 & $23 \overline{1}$ \\
\hline \multirow[t]{6}{*}{8} & \multirow[t]{5}{*}{1.6254} & 1.6246 & 5 & 036 \\
\hline & & 1.6150 & 3 & 01 \\
\hline & & 1.6006 & 2 & $32 \overline{2}$ \\
\hline & & 1.5937 & 8 & 315 \\
\hline & & 1.5800 & 2 & $\begin{array}{lll}404 & 4\end{array}$ \\
\hline & \multirow[b]{2}{*}{1.5663} & 1.5689 & 26 & 14 \\
\hline \multirow[t]{2}{*}{48} & & 1.5539 & 10 & 217 \\
\hline & \multirow{3}{*}{1.5122} & 1.5128 & 4 & $22 \overline{6}$ \\
\hline \multirow[t]{2}{*}{3} & & 1.5051 & 1 & 208 \\
\hline & & 1.4878 & 1 & 04 \\
\hline \multirow[t]{2}{*}{29} & \multirow[t]{2}{*}{1.4788} & 1.4785 & 20 & 1 \\
\hline & & 1.4767 & 8 & \\
\hline
\end{tabular}

(b) Mojaveite

\begin{tabular}{|c|c|c|c|c|c|c|c|c|c|}
\hline 5 & 6.34 & 6.320 & 9 & 101 & & & 1.735 & 1 & 042 \\
\hline 10 & 4.868 & 4.874 & 9 & $\begin{array}{lll}0 & 1 & 2\end{array}$ & \multirow[b]{2}{*}{4} & \multirow{3}{*}{1.700} & 1.709 & 4 & $\begin{array}{ll}31 \overline{4} \\
\end{array}$ \\
\hline 91 & 4.403 & 4.420 & 92 & $\begin{array}{lll}0 & 0 & 3\end{array}$ & & & 1.676 & 8 & 027 \\
\hline 7 & 4.167 & 4.151 & 7 & $\begin{array}{lll}11 & 1\end{array}$ & & & 1.637 & 2 & $23 \overline{1}$ \\
\hline 5 & 3.474 & 3.470 & 1 & $\begin{array}{lll}02 & 1\end{array}$ & \multirow[t]{5}{*}{5} & \multirow[t]{5}{*}{1.627} & 1.625 & 5 & 036 \\
\hline 1 & 3.172 & 3.160 & 4 & 202 & & & 1.615 & 3 & $\begin{array}{lll}0 & 1 & 8\end{array}$ \\
\hline & & 3.026 & 5 & 113 & & & 1.601 & 2 & $32 \overline{2}$ \\
\hline 2 & 3.014 & 3.010 & 12 & 104 & & & 1.594 & 8 & 315 \\
\hline 28 & 2.672 & 2.662 & 27 & $\begin{array}{lll}2 & 11\end{array}$ & & & 1.580 & 2 & 404 \\
\hline 100 & 2.512 & 2.514 & 100 & $21 \overline{2}$ & \multirow[t]{5}{*}{39} & \multirow[t]{5}{*}{1.570} & 1.569 & 26 & 140 \\
\hline & & 2.488 & 3 & $\begin{array}{lll}0 & 1 & 5\end{array}$ & & & 1.554 & 10 & 217 \\
\hline & & 2.437 & 11 & 024 & & & 1.513 & 4 & $22 \overline{6}$ \\
\hline 2 & 2.413 & 2.397 & 7 & 300 & & & 1.505 & 1 & 208 \\
\hline 5 & 2.201 & 2.210 & 1 & 006 & & & 1.488 & 1 & 045 \\
\hline & & 2.134 & 4 & 205 & \multirow[t]{4}{*}{34} & \multirow[t]{4}{*}{1.481} & 1.479 & 20 & $14 \overline{3}$ \\
\hline & & 2.107 & 9 & 033 & & & 1.477 & 8 & 324 \\
\hline 27 & 2.110 & 2.102 & 21 & 214 & & & 1.430 & 2 & $\begin{array}{lll}0 & 51\end{array}$ \\
\hline & & 2.075 & 6 & 220 & & & 1.415 & 1 & $21 \overline{8}$ \\
\hline & & 1.972 & 4 & $\begin{array}{lll}3 & 1 \overline{1}\end{array}$ & \multirow[t]{4}{*}{5} & \multirow[t]{3}{*}{1.407} & 1.401 & 1 & $32 \overline{5}$ \\
\hline 11 & 1.951 & 1.952 & 13 & 116 & & & 1.388 & 8 & 119 \\
\hline & & 1.910 & 12 & 312 & & & 1.384 & 1 & 330 \\
\hline \multirow[t]{4}{*}{34} & 1.889 & 1.898 & 40 & $21 \overline{5}$ & & & 1.373 & 2 & $31 \overline{7}$ \\
\hline & & 1.879 & 5 & $22 \overline{3}$ & 3 & 1.354 & 1.352 & 5 & $42 \overline{1}$ \\
\hline & & 1.832 & 4 & 107 & \multirow[t]{2}{*}{14} & \multirow[t]{2}{*}{1.338} & 1.331 & 10 & 422 \\
\hline & & 1.781 & 1 & $\begin{array}{lll}4 & 0 & 1\end{array}$ & & & & & \\
\hline
\end{tabular}


dimensions when it was noted that the $a$ parameter is very similar to those of spangolite $\left(\mathrm{Cu}_{6} \mathrm{Al}\left(\mathrm{SO}_{4}\right)(\mathrm{OH})_{12} \mathrm{Cl} .3 \mathrm{H}_{2} \mathrm{O}, P 31 c, a=8.254 \AA\right.$ and $c=14.354 \AA$; Hawthorne et al., 1993) and fuettererite $\left(\mathrm{Pb}_{3} \mathrm{Cu}_{6} \mathrm{Te}^{6+} \mathrm{O}_{6}(\mathrm{OH})_{7} \mathrm{Cl}_{5}, \quad R 3, a=\right.$ $8.404 \AA$ and $c=44.681 \AA$; Kampf et al., $2013 a$ ). Both of these structures have trigonal symmetry and contain brucite-like $\mathrm{Cu}_{6} M X_{14}$ structural layers, where $M=$ non- $\mathrm{Cu}^{2+}$ cation and $X=$ unspecified anion $(\mathrm{O}, \mathrm{OH}$ and $\mathrm{Cl})$. In both of these cases, the $\mathrm{Cu}^{2+}$ and $M$ are ordered in a hexagonal $\sqrt{ } 7 \times \sqrt{ } 7$ superstructure in the $x y$ plane, $M$ and $\mathrm{Cl}$ are situated on threefold axes, and the rotational sense of the threefold axes is determined by orientational order of Jahn-Teller distorted $\mathrm{Cu} X_{6}$ octahedra. While both spangolite and fuettererite have additional species between their layers, the absence of analysed elements other than $\mathrm{Cu}, \mathrm{I}, \mathrm{O}$ and $\mathrm{Cl}$ suggests that bluebellite layers have the same stoichiometry $\mathrm{Cu}_{6}^{2+} \mathrm{I}^{5+} \mathrm{O}_{3}(\mathrm{OH})_{10} \mathrm{Cl}$ as the bulk mineral, and that the structure is a simple rhombohedral stacking of such layers. Such a structure includes the motif of three $\mathrm{CuO}_{4}$ squares in a ring, described above. On this basis, a structure model for bluebellite was evolved by iterative manual adjustment of coordinates, visualizing the resulting structure and calculating intertaomic distances using

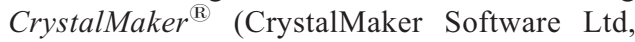
Oxford, UK; www.crystalmaker.com). The bond-distance and bond-valence parameters of Brese and O'Keeffe (1991) were employed.

An initial set of atomic coordinates was calculated, assuming that all $(\mathrm{Cu}, \mathrm{I}) X_{6}$ octahedra were regular and of equal size. Initially, it was suspected that the $\mathrm{I}^{5+}$ might sit above or below one of the (001) faces of a vacant octahedron, at the apex of an $\mathrm{IO}_{3}$ pyramid, but attempts to create such a model showed that there is insufficient interlayer space to accommodate $\mathrm{I}^{5+}$ in such a location, and that it must be located inside an $\mathrm{O}_{3}(\mathrm{OH})_{3}$ octahedron, albeit displaced from the centre. Modelling also revealed that one of the two distinct senses of rhombohedral stacking brought $\mathrm{I}^{5+}$ and $\mathrm{Cl}$ into unrealistically close juxtaposition, while the other kept them apart, but allowed formation of a well-defined H-bond network across the interlayer space, including a short, linear $\mathrm{O}-\mathrm{H} \cdots \mathrm{Cl}$ link. The layer has an ordered superstructure of the brucite type, as is found in the structures of many $\mathrm{OH}-\mathrm{rich} \mathrm{Cu}^{2+}$ oxycompounds (Hawthorne and Schindler, 2000). Bluebellite and mojaveite are related closely to the layered double hydroxides of the hydrotalcite supergroup (Mills et al., 2012), but are not members of that supergroup, because discrete interlayer species are absent, and also because there is substitution of $\mathrm{Cl}$ for $\mathrm{OH}$ in the brucitelike layer.

Once a plausible bond topology was established, a bond-valence table was constructed, bond valences adjusted so as to minimize meansquared deviations of bond-valence sums on all atoms, and the resulting bond valences were used to calculate target bond distances. Coordinates were then relaxed through a set of manual iterations, first so as to approximate these target bond distances, and then to match the ideal bondvalence sums as closely as possible.

During optimization of the model, the linear $\mathrm{O} 2-\mathrm{H} 2 \cdots \mathrm{Cl}$ moiety was moved $\pm \mathbf{c}$ as a rigid unit, given the short non-bonded $\mathrm{O} 2 \cdots \mathrm{Cl}$ distance. Accommodation of this rod-like element resulted in slight corrugation of the $(\mathrm{Cu} 1, \mathrm{Cu} 2, \mathrm{I})$ sheet, such that $z$ coordinates were $\mathrm{I}<\mathrm{Cu} 1<\mathrm{Cu} 2$. During later iterations, the $\mathrm{OH}$ groups were also moved as rigid units, apart from a final adjustment of $\mathrm{H} z$ coordinates to optimise bond-valence sums on $\mathrm{H}$.

It was found that coordinates could be adjusted so that the root-mean-squared deviation from ideal bond-valence sums was $<0.9 \%$ relative and $0.015 \mathrm{vu}$ absolute. Final positions for all atoms are shown in Table 4, with selected bond distances in Table 5 and bond valences are shown in Table 6. Neither $\mathrm{Cu} X_{6}$ octahedron showed the typical $4+2$ Jahn-Teller elongation: although the longest $\mathrm{Cu} 1-\mathrm{O}$ bond (to $\mathrm{O} 3$ ) was

TABLE 4. Fractional coordinates for the bluebellite structure model.

\begin{tabular}{lccl}
\hline Atom & $x$ & $y$ & \multicolumn{1}{c}{$z$} \\
\hline Cu1 & 0.289 & 0.376 & 0.026 \\
Cu2 & 0.689 & 0.568 & 0.053 \\
I & 0 & 0 & 0 \\
O1 & 0.122 & 0.493 & 0.976 \\
O2 & $2 / 3$ & $1 / 3$ & 0.993 \\
O3 & 0.252 & 0.129 & 0.950 \\
O4 & 0.456 & 0.356 & 0.121 \\
O5 & 0.072 & 0.219 & 0.124 \\
Cl & $1 / 3$ & $2 / 3$ & 0.104 \\
H1 & 0.051 & 0.465 & 0.911 \\
H2 & $2 / 3$ & $1 / 3$ & 0.915 \\
H3 & 0.051 & 0.150 & 0.189 \\
H4 & 0.461 & 0.313 & 0.193 \\
& & & \\
\hline
\end{tabular}


TABLE 5. Selected bond lengths for the bluebellite model (in $\AA$ ).

\begin{tabular}{ll}
\hline $\mathrm{Cu} 1-\mathrm{O} 1$ & 2.079 \\
$\mathrm{Cu} 1-\mathrm{O} 1^{\prime}$ & 2.156 \\
$\mathrm{Cu} 1-\mathrm{O} 3$ & 2.163 \\
$\mathrm{Cu} 1-\mathrm{O} 4$ & 1.939 \\
$\mathrm{Cu} 1-\mathrm{O} 5$ & 2.068 \\
$\mathrm{Cu} 1-\mathrm{Cl}$ & 2.494 \\
& \\
$\mathrm{Cu} 2-\mathrm{O} 1$ & 2.083 \\
$\mathrm{Cu} 2-\mathrm{O} 2$ & 2.024 \\
$\mathrm{Cu} 2-\mathrm{O} 3$ & 2.047 \\
$\mathrm{Cu} 2-\mathrm{O} 4$ & 2.060 \\
$\mathrm{Cu} 2-\mathrm{O} 4{ }^{\prime}$ & 2.065 \\
$\mathrm{Cu} 2-\mathrm{O} 5$ & 2.292 \\
& \\
$\mathrm{I}-\mathrm{O} 3(\times 3)$ & 1.928 \\
$\mathrm{I}-\mathrm{O} 5(\times 3)$ & 2.295 \\
& \\
\hline
\end{tabular}

trans to the long $\mathrm{Cu}-\mathrm{Cl}$ bond, the other four $\mathrm{Cu} 1-\mathrm{O}$ distances showed a broad spread; $\mathrm{Cu} 2$ is in $5+1$ coordination. The latter arises because $\mathrm{O} 3$ and $\mathrm{O} 5$ each form a short bond to one of $\mathrm{Cu} 1$ or $\mathrm{Cu} 2$ and a long bond to the other $\mathrm{Cu}$, in addition to a strong bond to I. As $\mathrm{Cu} 1$ forms a long bond to $\mathrm{O} 3, \mathrm{Cu} 2$ must make its long bond with $\mathrm{O} 5$, but although the $\mathrm{Cu} 2-\mathrm{O} 2$ bond is opposite the long $\mathrm{Cu} 2-\mathrm{O} 5$ link, it cannot itself elongate without underbonding of $\mathrm{O} 2$. The need for three strong bonds from $\mathrm{Cu} 2$ to the hydroxide oxygen $\mathrm{O} 2$ prevents adoption of the $4+2$ geometry for $\mathrm{Cu} 2$ in the bluebellite layer, in contrast to fuettererite, where this $\mathrm{OH}$ is replaced by a weakly bound $\mathrm{Cl}$ shared between two layers, or to $\mathrm{Cu} X_{2}$ sheets where the presence of $\mathrm{H}_{2} \mathrm{O}$ or $\mathrm{SO}_{4}$ oxygens facilitates the formation and ordering of long $\mathrm{Cu}-\mathrm{O}$ bonds (Hawthorne and Schindler, 2000; Hawthorne and Cooper, 2013). Bond angles deviated greatly from $90^{\circ}$, as noted for spangolite by Hawthorne et al. (1993). Hence, it was decided that this model, although capable of further optimization, shows the true structural topology of bluebellite (Fig. 9). Unfortunately, due to the quality of powder patterns obtained from the small amount of material available, this model could not be refined using the Rietveld method.

The crystal structure of mojaveite (Fig. 10) was modelled based on the bluebellite structure. Analogously to bluebellite, the absence of analysed elements other than $\mathrm{Cu}, \mathrm{Te}, \mathrm{O}$ and $\mathrm{Cl}$ in mojaveite, suggests that the structure is a simple rhombohedral stacking of $\mathrm{Cu}_{6} \mathrm{Te} X_{13} \mathrm{Cl}$ layers. This implies an extremely close structural relationship to fuettererite, in which pairs of such layers are linked through a shared $X$ anion $(\mathrm{Cl})$ to produce a $\mathrm{Cu}_{12} \mathrm{Te}_{2}^{6+} \mathrm{O}_{12}(\mathrm{OH})_{12} \mathrm{Cl}_{3}$ double layer that intercalates with thick interlayer slabs of composition $\mathrm{Pb}_{6}(\mathrm{OH})_{2} \mathrm{Cl}_{2}$ to build the structure (Kampf et al., 2013a). In contrast, the mojaveite structure is obtained by stacking of unpaired $\mathrm{Cu}-\mathrm{Te}$ layers in which the linking $\mathrm{Cl}$ ion is replaced by $\mathrm{OH}$ and 2 out of 6 tellurate oxygens are protonated for charge balance, to give the ideal formula $\mathrm{Cu}_{6} \mathrm{Te}^{6+} \mathrm{O}_{4}(\mathrm{OH})_{9} \mathrm{Cl}$.

As for bluebellite, a structure model for mojaveite was evolved using CrystalMaker ${ }^{\mathbb{R}}$ (CrystalMaker Software Ltd, Oxford, UK; www.crystalmaker.com). Initial trial positions for atoms were derived from those of fuettererite, by exchange of $x$ and $y$ coordinates and rescaling

TABLE 6. Bond-valence sums for the bluebellite model. Values are expressed in valence units.

\begin{tabular}{|c|c|c|c|c|c|c|c|}
\hline & $\mathrm{O} 1$ & $\mathrm{O} 2$ & $\mathrm{O} 3$ & O4 & O5 & $\mathrm{Cl}$ & $\Sigma$ \\
\hline $\mathrm{Cu} 1$ & $\begin{array}{l}0.34 \\
0.28\end{array}$ & & 0.27 & 0.50 & 0.35 & $\begin{array}{c}0.26 \\
\times 3 \downarrow\end{array}$ & 1.99 \\
\hline $\mathrm{Cu} 2$ & 0.34 & $\begin{array}{r}0.39 \\
\times 3 \downarrow\end{array}$ & 0.37 & $\begin{array}{l}0.36 \\
0.35\end{array}$ & 0.19 & & 2.00 \\
\hline I & & & $\begin{array}{l}1.21 \\
\times 3 \rightarrow\end{array}$ & & $\begin{array}{l}0.45 \\
\times 3 \rightarrow\end{array}$ & & 4.99 \\
\hline H1 & 0.87 & & & & 0.14 & & 1.01 \\
\hline $\mathrm{H} 2$ & & 0.80 & & & & 0.20 & 1.01 \\
\hline H3 & 0.14 & & & & 0.88 & & 1.01 \\
\hline $\mathrm{H} 4$ & & & 0.18 & 0.82 & & & 1.00 \\
\hline$\Sigma$ & 1.95 & 1.98 & 2.04 & 2.02 & 2.01 & 0.99 & \\
\hline
\end{tabular}



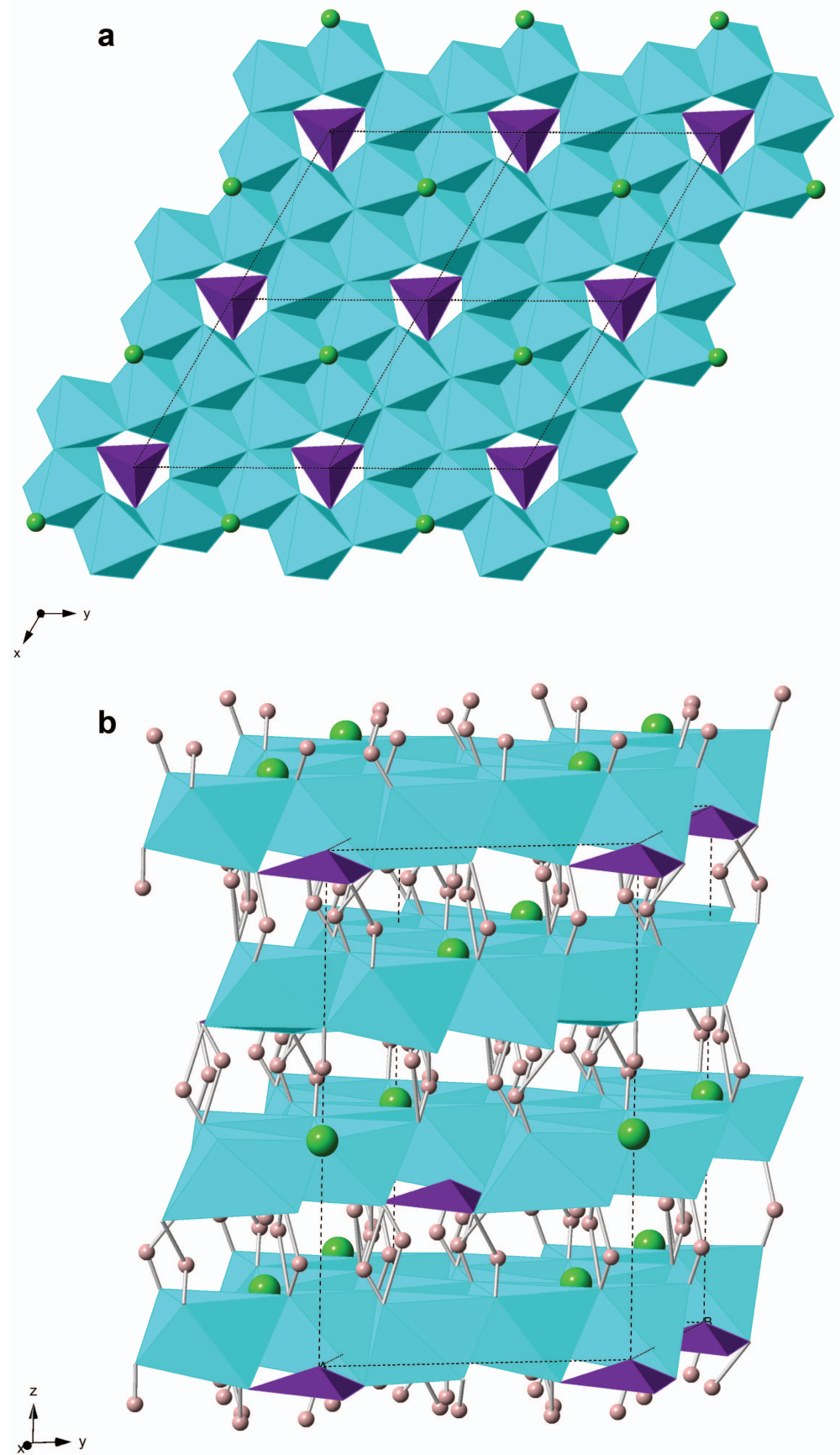

Fig. 9. Model crystal structure for bluebellite. $\mathrm{Cu} X_{6}$ octahedra are cyan, $\mathrm{IO}_{3}$ pyramids are violet (three additional longer bonds to $\mathrm{O}$ are not shown for clarity), $\mathrm{Cl}$ are indicated by large green spheres, and $\mathrm{H}$ by small pink spheres. (a) Single $\mathrm{Cu}_{6} \mathrm{~L} X_{14}$ layer viewed from $+\mathbf{c}$. (b) View of structure from nearly $+\mathbf{a}$, showing stacking of layers and $\mathrm{H}$ bonding between layers. 

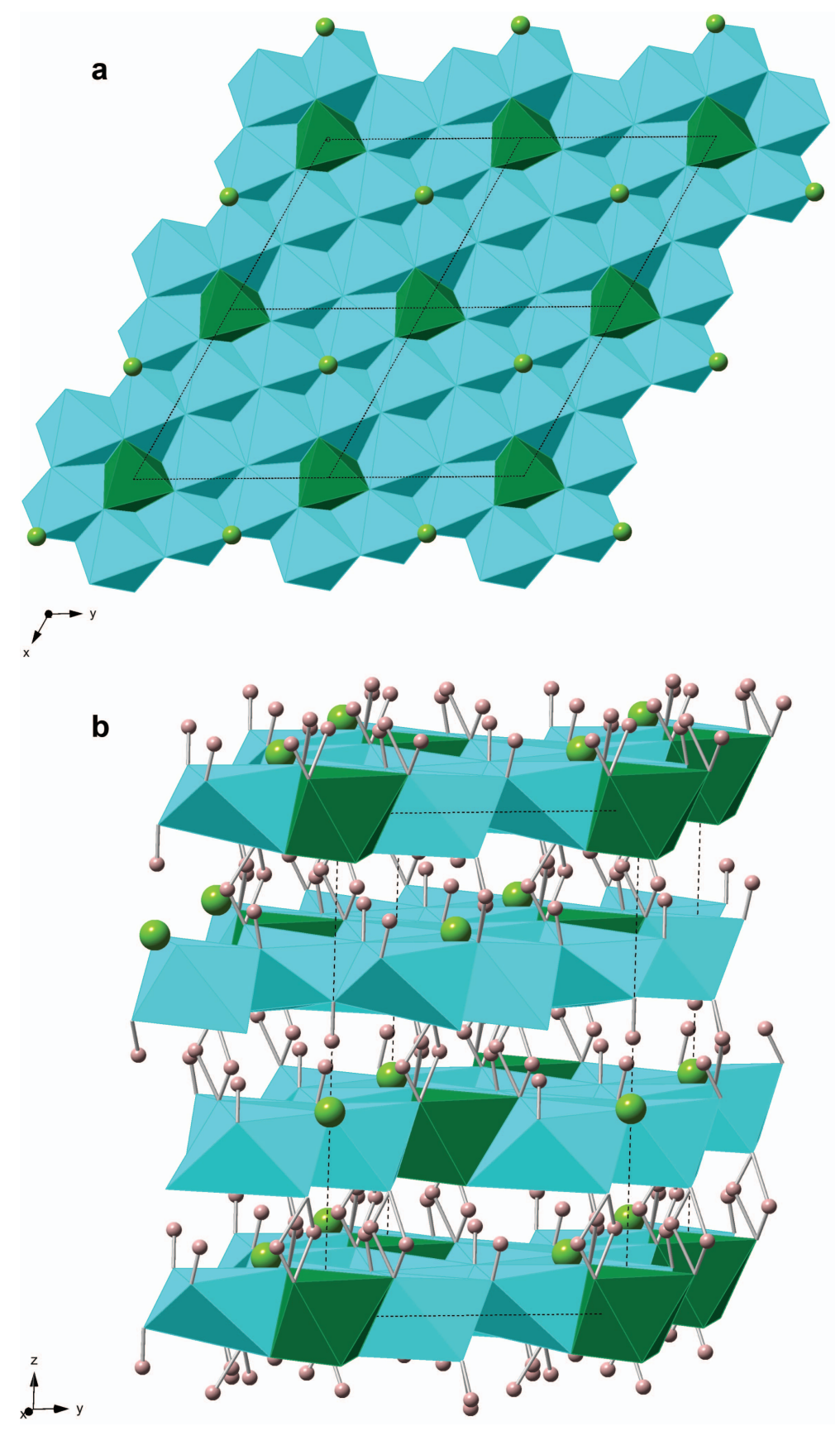

FIG. 10. Model crystal structure for mojaveite. $\mathrm{Cu} X_{6}$ octahedra are cyan, $\mathrm{TeO}_{6}$ octahedra are dark green, $\mathrm{Cl}$ are indicated by pale green spheres, and $\mathrm{H}$ by small pink spheres. (a) Single $\mathrm{Cu}_{6} \mathrm{Te} X_{14}$ layer viewed from $+\mathbf{c}$. (b) View of structure from nearly $+\mathbf{a}$, showing stacking of layers and $\mathrm{H}$ bonding between layers. 
of $z$. The topology deduced for mojaveite was then used to create a bond-valence table, and bond valences were iteratively adjusted so as to minimize mean-squared deviations from the ideal of bond-valence sums on all atoms. It was assumed that the $\mathrm{TeO}_{4}(\mathrm{OH})_{2}$ octahedron of mojaveite was derived from the $\mathrm{IO}_{3}(\mathrm{OH})_{3}$ distorted octahedron of bluebellite by reducing the occupancy of $\mathrm{H} 3$ to $2 / 3$. Optimized bond valences were then converted to ideal bond distances using the bond-distance - bondvalence parameters of Brese and O'Keeffe (1991), except for $\mathrm{Te}-\mathrm{O}$, for which the parameters of Mills and Christy (2013) were employed. Atom coordinates were then relaxed iteratively so as to minimize deviation of bond distances from the predicted values and a further set of iterations was used to optimize bondvalence sums. The optimization was limited by the need to avoid short non-bonded distances from $\mathrm{H} 1$ and $\mathrm{H} 3$ to $\mathrm{Cu} 1, \mathrm{Cu} 2$ and each other, and between $\mathrm{O} 2$ and $\mathrm{O} 4$. As for bluebellite, the linear $\mathrm{O} 2-\mathrm{H} 2 \cdots \mathrm{Cl}$ moiety was treated as a rigid rodlike unit. The minimum root-mean-squared deviation from ideal bond-valence sums obtained was $1.8 \%$ relative and $0.035 \mathrm{vu}$ absolute. The resulting coordinates, selected bond lengths and bond valences are given in Tables 7-9.

The bond network of mojaveite necessarily requires the high-valence cation to be in distorted $3+3$ coordination, but the difference between the two bond distances is much less for $\mathrm{Te}^{6+}$ than for the $\mathrm{I}^{5+}$ of bluebellite (Tables 5 and 8 ). As for

TABLE 7. Fractional coordinates for the mojaveite model.

\begin{tabular}{lccl}
\hline Atom & $x / a$ & $y / b$ & $z / c$ \\
\hline $\mathrm{Cu} 1$ & 0.293 & 0.401 & 0.965 \\
$\mathrm{Cu} 2$ & 0.703 & 0.580 & 0.001 \\
$\mathrm{Te}$ & 0 & 0 & 0 \\
$\mathrm{O} 1$ & 0.122 & 0.486 & 0.920 \\
$\mathrm{O} 2$ & $2 / 3$ & $1 / 3$ & 0.959 \\
$\mathrm{O} 3$ & 0.193 & 0.101 & 0.916 \\
$\mathrm{O} 4$ & 0.465 & 0.389 & 0.065 \\
$\mathrm{O} 5$ & 0.065 & 0.242 & 0.083 \\
$\mathrm{Cl}$ & $1 / 3$ & $2 / 3$ & 0.074 \\
$\mathrm{H} 1$ & 0.183 & 0.530 & 0.847 \\
$\mathrm{H} 2$ & $2 / 3$ & $1 / 3$ & 0.880 \\
$\mathrm{H} 3 *$ & 0.127 & 0.293 & 0.153 \\
$\mathrm{H} 4$ & 0.436 & 0.382 & 0.139 \\
& & & \\
\hline
\end{tabular}

* H3 is $66.7 \%$ occupied.

bluebellite, the $(\mathrm{Cu}, \mathrm{Te})$ layer is somewhat corrugated so as to accommodate the short $\mathrm{O} 2-\mathrm{H} 2 \cdots \mathrm{Cl}$ link, but in a different pattern, with the $z$ coordinates $\mathrm{Cu} 1<\mathrm{Te} \approx \mathrm{Cu} 2$ as $\mathrm{Te}$, unlike $\mathrm{I}$, is not strongly displaced towards the lower face of its octahedron (Table 7). Also, similarly to bluebellite, the $\mathrm{Cu}-X$ distances do not show the usual $4+2$ pattern due to Jahn-Teller distortion. While $\mathrm{Cu} 1$ does show a long $\mathrm{Cu}-\mathrm{O} 3$ bond trans to the long $\mathrm{Cu}-\mathrm{Cl}, \mathrm{Cu} 1-\mathrm{O} 5$ is also quite long; $\mathrm{Cu} 2$ shows a $2+3+1$ distribution of $\mathrm{Cu}-\mathrm{O}$ distances over 1.99-2.22 $\AA$ (Table 8), although the two longest bonds to $\mathrm{O} 4$ and $\mathrm{O} 1$ are trans to each other. Again, Rietveld refinement was not possible, given the poor quality of the powder patterns yielded by the very scarce material.

The detection of minor $\mathrm{Pb}, \mathrm{Bi}$ and excess $\mathrm{Cl}$ in the analysis of mojaveite (Table 2) is interesting in the light of the deduced relationship to fuettererite, in which additional $\mathrm{Pb}$ and $\mathrm{Cl}$ are essential major components. The octahedral sites of mojaveite are too small to contain $\mathrm{Pb}^{2+}$. Examination of the interlayer reveals that there are approximately trigonal prismatic interstices between the upper anions of one layer and the lower anions of the next, but these sites are also rather small for $\mathrm{Pb}$; the largest such voids are located at approximately $(0.30,0.425,0.19)$, and are surrounded by $5 \mathrm{O}+1 \mathrm{Cl}$ at $2.2-2.5 \AA$, which would give a bond-valence sum of more than $4 \mathrm{vu}$ on $\mathrm{Pb}^{2+}$. It is, therefore, very unlikely that the extra ions are located in low-occupancy sites in the interlayer gap of the ideal mojaveite structure.

TABLE 8. Selected bond lengths for the mojaveite model $(\AA)$.

\begin{tabular}{ll}
\hline $\mathrm{Cu} 1-\mathrm{O} 1$ & 1.982 \\
$\mathrm{Cu} 1-\mathrm{O} 1^{\prime}$ & 2.002 \\
$\mathrm{Cu} 1-\mathrm{O} 3$ & 2.305 \\
$\mathrm{Cu} 1-\mathrm{O} 4$ & 1.959 \\
$\mathrm{Cu} 1-\mathrm{O} 5$ & 2.267 \\
$\mathrm{Cu} 1-\mathrm{Cl}$ & 2.492 \\
& \\
$\mathrm{Cu} 2-\mathrm{O} 1$ & 2.136 \\
$\mathrm{Cu} 2-\mathrm{O} 2$ & 1.997 \\
$\mathrm{Cu} 2-\mathrm{O} 3$ & 2.124 \\
$\mathrm{Cu} 2-\mathrm{O} 4$ & 2.003 \\
$\mathrm{Cu} 2-\mathrm{O} 4{ }^{\prime}$ & 2.218 \\
$\mathrm{Cu} 2-\mathrm{O} 5$ & 2.131 \\
& \\
$\mathrm{Te}-\mathrm{O} 3(\times 3)$ & 1.779 \\
$\mathrm{Te}-\mathrm{O} 5(\times 3)$ & 2.111 \\
\end{tabular}


TABLE 9. Bond-valence sums for the mojaveite model. Values are expressed in valence units.

\begin{tabular}{|c|c|c|c|c|c|c|c|}
\hline & O1 & $\mathrm{O} 2$ & $\mathrm{O} 3$ & O4 & O5 & $\mathrm{Cl}$ & $\Sigma$ \\
\hline $\mathrm{Cu} 1$ & $\begin{array}{l}0.44 \\
0.42\end{array}$ & & 0.18 & 0.47 & 0.20 & $\begin{array}{r}0.26 \\
\times 3 \downarrow\end{array}$ & 1.98 \\
\hline $\mathrm{Cu} 2$ & 0.29 & $\begin{array}{c}0.42 \\
\times 3 \downarrow\end{array}$ & 0.30 & $\begin{array}{l}0.42 \\
0.23\end{array}$ & 0.30 & & 1.96 \\
\hline $\mathrm{Te}$ & & & $\begin{array}{r}1.29 \\
\times 3 \rightarrow\end{array}$ & & $\begin{array}{r}0.71 \\
\times 3 \rightarrow\end{array}$ & & 6.01 \\
\hline H1 & 0.73 & & & & 0.26 & & 1.00 \\
\hline $\mathrm{H} 2$ & & 0.78 & & & & 0.22 & 1.00 \\
\hline H3 & $\begin{array}{r}0.21 \\
\times 2 / 3 \downarrow\end{array}$ & & & & $\begin{array}{l}0.79 \\
\times 2 / 3 \downarrow\end{array}$ & & 1.00 \\
\hline $\mathrm{H} 4$ & & & 0.12 & 0.87 & & & 0.99 \\
\hline$\Sigma$ & 2.02 & 2.05 & 1.89 & 1.99 & 2.00 & 1.01 & \\
\hline
\end{tabular}

However, the structure of fuettererite suggests that $(\mathrm{Pb}, \mathrm{Bi})+\mathrm{Cl}$ could be accommodated by intercalation of a $(\mathrm{Pb}, \mathrm{Cl})$-rich slab similar to that of fuettererite between a small percentage of mojaveite sheets. Such disorder could explain the streaking parallel to $c^{*}$ observed in single-crystal XRD.

\section{Acknowledgements}

Two anonymous reviewers are thanked for helpful suggestions which improved the manuscript. Quintin Johnson of Materials Data, Inc., is thanked for conducting the initial structure solution using the RUBY program. Part of this study has been funded by The Ian Potter Foundation grant "tracking tellurium" to SJM which is gratefully acknowledged. The microprobe analyses were supported by a grant to Caltech from the Northern California Mineralogical Association. The XRD analyses were funded by the John Jago Trelawney Endowment to the Mineral Sciences Department of the Natural History Museum of Los Angeles County.

\section{References}

Brese, N.E. and O'Keeffe, M. (1991) Bond-valence parameters for solids. Acta Crystallographica, B47, 192-197.

Crowley, J.A. (1977) Minerals of the Blue Bell mine, San Bernardino County, California. Mineralogical Record, 8, 494-496, 518.

Dunning, G.E., Hadley, T.A., Christy, A.G., Magnasco, J. and Cooper, J.F. Jr. (2005) The Clear Creek mine,
San Benito County, California - A unique mercury locality. Mineralogical Record, 36, 337-363.

Frost, R.L. (2009) Tlapallite $\mathrm{H}_{6}(\mathrm{Ca}, \mathrm{Pb})_{2}(\mathrm{Cu}, \mathrm{Zn})_{3} \mathrm{SO}_{4}$ $\left(\mathrm{TeO}_{3}\right)_{4} \mathrm{TeO}_{6}$, a multi-anion mineral: a Raman spectroscopic study. Spectrochimica Acta, Part A, 72, 903-906.

Frost, R.L. and Keeffe, E.C. (2009a) Raman spectroscopic study of the mixed anion mineral yecoraite, $\mathrm{Bi}_{5} \mathrm{Fe}_{3} \mathrm{O}_{9}\left(\mathrm{Te}^{4+} \mathrm{O}_{3}\right)\left(\mathrm{Te}^{6+} \mathrm{O}_{4}\right)_{2} \cdot 9 \mathrm{H}_{2} \mathrm{O}$. Journal of Raman Spectroscopy, 40, 1117-1120.

Frost, R.L. and Keeffe, E.C. (2009b) Raman spectroscopic study of kuranakhite $\mathrm{PbMn}^{4+} \mathrm{Te}^{6+} \mathrm{O}_{6}-$ a rare tellurate mineral. Journal of Raman Spectroscopy, 40, 249-252.

Girase, K., Sawant, D.K., Patil, H.M. and Bhavsar, D.S. (2013) Thermal, FTIR and Raman spectral analysis of $\mathrm{Cu}(\mathrm{II})$-doped lead iodate crystals. Journal of Thermal Analysis and Calorimetry, 111, 267-271.

Hawthorne, F.C. and Cooper, M.A. (2013) The crystal structure of chalcoalumite: mechanisms of JahnTeller-driven distortion in ${ }^{[6]} \mathrm{Cu}^{2+}$-containing oxysalts. Mineralogical Magazine, 77, 2901-2912.

Hawthorne, F.C. and Schindler, M. (2000) Topological enumeration of decorated $\left[\mathrm{Cu}^{2+} \varphi_{2}\right]_{\mathrm{N}}$ sheets in hydroxy-hydrated copper-oxysalt minerals. The Canadian Mineralogist, 38, 751-761.

Hawthorne, F.C., Kimata, M. and Eby, R.K. (1993) The crystal structure of spangolite, a complex copper sulfate sheet mineral. American Mineralogist, 78, 649-652.

Housley, R.M., Kampf, A.R., Mills, S.J., Marty, J. and Thorne, B. (2011) The remarkable occurrence of rare secondary tellurium minerals at Otto Mountain near Baker, California - including seven new species. Rocks and Minerals, 86, 132-142.

Kampf, A.R. and Housley, R.M. (2011) Fluorphosphohedyphane, $\mathrm{Ca}_{2} \mathrm{~Pb}_{3}\left(\mathrm{PO}_{4}\right)_{3} \mathrm{~F}$, the first 
apatite supergroup mineral with essential $\mathrm{Pb}$ and $\mathrm{F}$. American Mineralogist, 96, 423-429.

Kampf, A.R., Rossman, G.R. and Housley, R.M. (2009) Plumbophyllite, a new species from the Blue Bell claims near Baker, San Bernardino County, California. American Mineralogist, 94, 1198-1204.

Kampf, A.R., Housley, R.M., Mills, S.J., Marty, J. and Thorne, B. (2010a) Lead-tellurium oxysalts from Otto Mountain near Baker, California: I. Ottoite, $\mathrm{Pb}_{2} \mathrm{TeO}_{5}$, a new mineral with chains of tellurate octahedra. American Mineralogist, 95, 1329-1336.

Kampf, A.R., Marty, J. and Thorne, B. (2010b) Leadtellurium oxysalts from Otto Mountain near Baker, California: II. Housleyite, $\mathrm{Pb}_{6} \mathrm{CuTe}_{4} \mathrm{TeO}_{18}(\mathrm{OH})_{2}$, a new mineral with $\mathrm{Cu}-\mathrm{Te}$ octahedral sheets. American Mineralogist, 95, 1337-1342.

Kampf, A.R., Housley, R.M. and Marty, J. (2010c) Leadtellurium oxysalts from Otto Mountain near Baker, California: III. Thorneite, $\mathrm{Pb}_{6}\left(\mathrm{Te}_{2} \mathrm{O}_{10}\right)\left(\mathrm{CO}_{3}\right)$ $\mathrm{Cl}_{2}\left(\mathrm{H}_{2} \mathrm{O}\right)$, the first mineral with edge-sharing octahedral dimers. American Mineralogist, 95, 1548-1553.

Kampf, A.R., Mills, S.J., Housley, R.M., Marty, J. and Thorne, B. (2010d) Lead-tellurium oxysalts from Otto Mountain near Baker, California: IV. Markcooperite, $\mathrm{Pb}_{2}\left(\mathrm{UO}_{2}\right) \mathrm{Te}^{6+} \mathrm{O}_{6}$, the first natural uranyl tellurate. American Mineralogist, 95, $1554-1559$.

Kampf, A.R., Mills, S.J., Housley, RM., Marty, J. and Thorne, B. (2010e) Lead-tellurium oxysalts from Otto Mountain near Baker, California: V. Timroseite, $\mathrm{Pb}_{2} \mathrm{Cu}_{5}^{2+}\left(\mathrm{Te}^{6+} \mathrm{O}_{6}\right)_{2}(\mathrm{OH})_{2}$, and paratimroseite, $\mathrm{Pb}_{2} \mathrm{Cu}_{4}^{2+}\left(\mathrm{Te}^{6+} \mathrm{O}_{6}\right)_{2}\left(\mathrm{H}_{2} \mathrm{O}\right)_{2}$, new minerals with edge-sharing $\mathrm{Cu}-\mathrm{Te}$ octahedral chains. American Mineralogist, 95, 1560-1568.

Kampf, A.R., Mills, S.J., Housley, R.M., Marty, J. and Thorne, B. (2010f) Lead-tellurium oxysalts from Otto Mountain near Baker, California: VI. Telluroperite, $\mathrm{Pb}_{3} \mathrm{Te}^{4+} \mathrm{O}_{4} \mathrm{Cl}_{2}$, the $\mathrm{Te}$ analogue of perite and nadorite. American Mineralogist, 95, $1569-1573$.

Kampf, A.R., Mills, S.J., Housley, R.M., Rumsey, M.S. and Spratt, J. (2012a) Lead-tellurium oxysalts from Otto Mountain near Baker, California: VII. Chromschieffelinite, $\mathrm{Pb}_{10} \mathrm{Te}_{6} \mathrm{O}_{20}\left(\mathrm{CrO}_{4}\right)\left(\mathrm{H}_{2} \mathrm{O}\right)_{5}$, the chromate analogue of schieffelinite. American Mineralogist, 97, 212-219.

Kampf, A.R., Mills, S.J., Housley, R.M., Bottrill, R.S. and Kolitsch, U. (2012b) Reynoldsite, $\mathrm{Pb}_{2} \mathrm{Mn}_{2}^{4+} \mathrm{O}_{5}\left(\mathrm{CrO}_{4}\right)$, a new phyllomanganate-chromate from the Blue Bell claims, California and the Red Lead mine, Tasmania. American Mineralogist, 97, 1187-1192.

Kampf, A.R., Mills, S.J., Housley, R.M. and Marty, J. (2013a) Lead-tellurium oxysalts from Otto Mountain near Baker, California: VIII. Fuettererite, $\mathrm{Pb}_{3} \mathrm{Cu}_{6}^{2+} \mathrm{Te}^{6+} \mathrm{O}_{6}(\mathrm{OH})_{7} \mathrm{Cl}_{5}$, a new mineral with double spangolite-type sheets. American Mineralogist, 97, 506-511.

Kampf, A.R., Mills, S.J., Housley, R.M. and Marty, J. (2013b) Lead-tellurium oxysalts from Otto Mountain near Baker, California: IX. Agaite, $\mathrm{Pb}_{3} \mathrm{Cu}^{2+} \mathrm{Te}^{6+} \mathrm{O}_{5}$ $(\mathrm{OH})_{2}\left(\mathrm{CO}_{3}\right)$, a new mineral with $\mathrm{CuO}_{5}-\mathrm{TeO}_{6}$ polyhedral sheets. American Mineralogist, 97, 512-517.

Kampf, A.R., Mills, S.J., Housley, R.M., Rossman, G.R., Marty, J. and Thorne, B. (2013c) Leadtellurium oxysalts from Otto Mountain near Baker, California: X. Bairdite, $\mathrm{Pb}_{2} \mathrm{Cu}_{4}^{2+} \mathrm{Te}_{2}^{6+} \mathrm{O}_{10}(\mathrm{OH})_{2}$ $\left(\mathrm{SO}_{4}\right) \cdot \mathrm{H}_{2} \mathrm{O}$, a new mineral with thick HCP layers. American Mineralogist, 97, 1315-1321.

Kampf, A.R., Mills, S.J., Housley, R.M., Rossman, G.R., Marty, J. and Thorne, B. (2013d) Leadtellurium oxysalts from Otto Mountain near Baker, California: XI. Eckhardite, $(\mathrm{Ca}, \mathrm{Pb}) \mathrm{Cu}^{2+} \mathrm{Te}^{6+} \mathrm{O}_{5}$ $\left(\mathrm{H}_{2} \mathrm{O}\right)$, a new mineral with HCP stair-step layers. American Mineralogist, 98, 1617-1623.

Maroni, V.A. and Hathaway, E.J. (1972) Laser Raman studies of the iodate ion in molten nitrate solutions. Journal of Inorganic and Nuclear Chemistry, 34, 3049-3053.

Maynard, M.F., Valenti, A., Jenkins, J., Jenkins, F., Hall, D., Hall, J., White, B., White, S., Mansfield, M. and Mansfield, E. (1984) The Blue Bell Claims. San Bernardino County Museum Special Publication, San Bernardino County Museum, San Bernardino, California, USA.

Mills, S.J. and Christy, A.G. (2013) Revised values of the bond valence parameters for $\mathrm{Te}^{\mathrm{IV}}-\mathrm{O}, \mathrm{Te}^{\mathrm{VI}}-\mathrm{O}$ and $\mathrm{Te}^{\mathrm{IV}}-\mathrm{Cl}$. Acta Crystallographica, B69, 145-149.

Mills, S.J., Kampf, A.R., Kolitsch, U., Housley, R.M. and Raudsepp, M. (2010) The crystal chemistry and crystal structure of kuksite, $\mathrm{Pb}_{3} \mathrm{Zn}_{3} \mathrm{Te}^{6+} \mathrm{P}_{2} \mathrm{O}_{14}$, and a note on the crystal structure of yafsoanite, $(\mathrm{Ca}, \mathrm{Pb})_{3} \mathrm{Zn}\left(\mathrm{TeO}_{6}\right)_{2}$. American Mineralogist, 95, 933-938.

Mills, S.J., Christy, A.G., Genin, J.-M.R., Kameda, T. and Colombo, F. (2012) Nomenclature of the hydrotalcite supergroup: natural layered double hydroxides. Mineralogical Magazine, 76, 1289-1336.

Mills, S.J., Kampf, A.R., Christy, A.G., Housley, R.M., Rossman, G.R. and Marty, J. (2014a) Mojaveite, IMA 2013-120. CNMNC Newsletter No. 20, June 2014, page 550. Mineralogical Magazine, 78, 549-558.

Mills, S.J., Kampf, A.R., Christy, A.G., Housley, R.M., Rossman, G.R. and Reynolds, R.R. (2014b) Bluebellite, IMA 2013-121. CNMNC Newsletter No. 20, June 2014, page 550. Mineralogical Magazine, 78, 549-558.

Schellenschläger, V., Pracht, G. and Lutz, H.D. (2001) Single-crystal Raman studies on nickel iodate 
dihydate, $\mathrm{Ni}\left(\mathrm{IO}_{3}\right)_{2} \cdot 2 \mathrm{H}_{2} \mathrm{O}$. Journal of Raman Spectroscopy, 32, 373-382.

Walker, J.D., Martin, M.W. and Glazner, A.F. (2002) Late Paleozoic to Mesozoic development of the Mojave Desert and environs, California. Pp. 1-18 in: Geologic Evolution of the Mojave Desert and Southwestern Basin and Range (A.F. Glazner, J.D. Walker and J.M. Bartley, (editors). Geological Society of America Memoir, 195. Geological Society of America, Boulder, Colorado, USA. 